\title{
Micronutrient levels and nutritional status of school children living in Northwest Ethiopia
}

\author{
Bemnet Amare ${ }^{1 *}$, Beyene Moges ${ }^{2}$, Bereket Fantahun ${ }^{3}$, Ketema Tafess ${ }^{2}$, Desalegn Woldeyohannes ${ }^{2}$, \\ Gizachew Yismaw ${ }^{2}$, Tilahun Ayane ${ }^{1}$, Tomoki Yabutani ${ }^{4}$, Andargachew Mulu ${ }^{2}$, Fusao Ota ${ }^{5}$ and Afework Kassu ${ }^{2}$
}

\begin{abstract}
Background: Several micronutrients are essential for adequate growth of children. However, little information is available on multiple micronutrient status of school children in Ethiopia. The present study was designed to evaluate the relationship between multiple micronutrient levels and nutritional status among school children.

Method: In this cross-sectional study, anthropometric data, blood and stool samples were collected from 100 children at Meseret Elementary School in Gondar town, Northwest Ethiopia. Serum concentration of magnesium, calcium, iron, copper, zinc, selenium and molybdenum were measured by inductively coupled plasma mass spectrometer. Anthropometric indices of weight-for-age, height-for-age and BMI-for-age were used to estimate the children's nutritional status. Stool samples were examined by standard microscopic methods for intestinal parasites.

Results: The prevalence of stunting, underweight, wasting and intestinal parasitoses among school children was $23 \%, 21 \%, 11 \%$ and $18 \%$, respectively. The mean serum levels of magnesium, calcium, iron, copper, zinc, selenium and molybdenum were $2.42 \pm 0.32(\mathrm{mg} / \mathrm{dl}), 15.31 \pm 2.14(\mathrm{mg} / \mathrm{dl}), 328.19 \pm 148.91(\mu \mathrm{g} / \mathrm{dl}), 191.30 \pm 50.17(\mu \mathrm{g} / \mathrm{dl})$, $86.40 \pm 42.40(\mu \mathrm{g} / \mathrm{dl}), 6.32 \pm 2.59(\mu \mathrm{g} / \mathrm{dl})$, and $0.23 \pm 0.15(\mu \mathrm{g} / \mathrm{dl})$, respectively. Selenium deficiency, zinc deficiency and magnesium deficiency occurred in $62 \%, 47 \%$, and $2 \%$ of the school children, respectively. Height-for-age showed significant positive correlation with the levels of copper and molybdenum $(p=0.01)$ and with the levels of magnesium ( $p=0.05)$.

Conclusion: Deficiencies of selenium and zinc were high among the school children although the deficiencies were not significantly related with their nutritional status. The prevalence of both malnutrition and intestinal parasitism was not negligible. These calls for the need to undertake multicentre studies in various parts of the country to substantiate the data obtained in the present study so that appropriate and beneficial strategies for micronutrient supplementation and interventions on nutritional deficiencies can be planned.
\end{abstract}

Keywords: School children, Nutritional status, Micronutrients, Gondar, Ethiopia

\section{Introduction}

There is a continuing worldwide effort focused on the complete eradication of poverty and hunger [1]. However, undernutrition is still a major public health problem especially in Sub-Saharan Africa [2]. In Ethiopia, child malnutrition continues to be a major public health problem [3].

Undernourished children are more likely to develop severe infections secondary to compromised immune res-

\footnotetext{
* Correspondence: amarebem6@gmail.com

'Department of Medical Biochemistry, University of Gondar, College of

Medicine and Health Sciences, Gondar, Ethiopia

Full list of author information is available at the end of the article
}

ponses [4]. Undernutrition influences several aspects of immunity, including cell-mediated immune responses [5], cytokine production [6] and antibody responses [7] particularly those that require $\mathrm{T}$ cell support [8]. The high prevalence of bacterial and parasitic diseases in poor countries contributes greatly to undernutrition [9].

Children are most vulnerable to undernutrition due to low dietary intake, inaccessibility to food, inequitable distribution of food within the household, improper food storage and preparation, dietary taboos and infectious diseases [9]. Especially, micronutrient deficiencies are a result of inadequate intake or inefficient utilization of available micronutrients due to infections and parasitic infestations

\section{Biomed Central}

(c) 2012 Amare et al.; licensee BioMed Central Ltd. This is an Open Access article distributed under the terms of the Creative Commons Attribution License (http://creativecommons.org/licenses/by/2.0), which permits unrestricted use, distribution, and reproduction in any medium, provided the original work is properly cited. 
[4]. However, information on the serum levels of multiple micronutrients in human biological tissues is scarce. For many essential elements, baseline levels in the general population, and especially in children, are lacking [10].

The levels in children are of particular interest since adequate intake of micronutrients is of great importance for the well being, proper development, and functioning of the body starting from fetal life and throughout childhood. They have been implicated to play important roles in immuno-physiologic functions [11]. For example, zinc is an integral part of more than 200 enzymes and has significant task in nucleic acid metabolism, cell replication, tissue repair, and growth [12]. The antioxidation functions of selenium in glutathione peroxidase are essential in protecting the biological system from oxidation caused by peroxides [13]. Superoxide dismutases, which usually contain copper and/or zinc, act as antioxidants against superoxides [13]. Iron carries oxygen to the cells and is necessary for the production of energy, the synthesis of collagen, and the functioning of the immune system [14-16] and copper is required with iron for synthesis of hemoglobin. It works with many enzymes such as those involved in protein metabolism and hormone synthesis [16]. Calcium plays an important role in muscle contraction and regulation of water balance in cells. Modification of plasma calcium concentration leads to the alteration of blood pressure. Magnesium has been known as an essential co-factor for many enzyme systems. It also plays an important role in neurochemical transmission and peripheral vasodilation [17].

Micronutrient deficiencies can affect all age groups, but young children are most at risk, particularly in the developing world [18]. According to previous estimates, micronutrient deficiency accounts for approximately $7.3 \%$ of the global burden of disease [10]. Although several studies have documented the status of one or two micronutrients among children [19-26], little information is available on multiple micronutrient status of school children. The present study was, therefore, designed to evaluate the relationship between nutritional status and level of multiple micronutrients in Ethiopian school children.

\section{Methods}

\section{Study area and subjects}

In this cross-sectional study, 100 students were selected by simple random sampling at Meseret Elementary School in Gondar town. Gondar town is located in the Northwestern part of Ethiopia with population of 200,000 [27]. None of the school children participated in this study received any of micronutrient supplementation.

\section{Ethical considerations}

The study was reviewed and approved by the Institutional Review Board (IRB) of the University of Gondar. Infor- med written consent was obtained from parents or legal guardians.

\section{Nutritional assessment}

Body weight was determined to the nearest $0.1 \mathrm{~kg}$ on an electronic digital scale and height was measured to the nearest $0.1 \mathrm{~cm}$. Overweight $(>+1 \mathrm{SD}$ BMI-for-age $\mathrm{z}$ score), obesity ( $>+2 \mathrm{SD}$ BMI-for-age $\mathrm{z}$ score), thinness/ wasting $(<-2 \mathrm{SD}$ of BMI-for-age $\mathrm{z}$ score), underweight $(<-2 \mathrm{SD}$ of weight-for-age $\mathrm{z}$ score) and stunting $(<-2 \mathrm{SD}$ of height-for-age (HAZ) z score) were defined according to the WHO and USCDC references [28]. Since weightfor-age (WAZ) is inadequate indicator for monitoring child growth beyond pre-school years due to its inability to distinguish between relative height and body mass, therefore, BMI-for-age is recommended by the WHO and USCDC to assess thinness/wasting in school-aged children and adolescents [29].

\section{Collection of stool specimens and examination for helminths}

Stool samples were collected following standard procedures in clean leak-proof stool cups. Just after collection they were examined by two senior clinical laboratory technicians independently for intestinal parasites following direct and concentration methods at Gondar University Hospital Parasitology Laboratory [30]. All children who were found to be positive for intestinal parasites were given the appropriate anti-parasite chemotherapy by a medical doctor.

\section{Determination of levels of trace elements in serum}

Blood specimens were taken with minimal venostasis after overnight fasting for the measurement of micronutrients by phlebotomists. The venous bloods were drawn into sterile non-contaminated polypropylene tubes (Becton Dickinson, Franklin Lakes, NJ, USA); All tubes were kept in dark cool boxes $\left(0-4^{\circ} \mathrm{C}\right)$ and transported to the Gondar University Hospital. Sera were separated from cells by centrifugation at $4000 \mathrm{~g}$ for $10 \mathrm{~min}$ at $4^{\circ} \mathrm{C}$, within 4 hours. Aliquots of sera were stored at $-70^{\circ} \mathrm{C}$ until analysis. For the determination of trace elements, sera were kept on dry ice and brought to the University of Tokushima, Japan.

Concentration of trace elements in serum was determined using an Inductively Coupled Plasma Mass Spectrometer (ICP-MS) (model 8500, Schimadzu, Tokyo, Japan), at Department of Analytical Chemistry, the University of Tokushima, Japan following previously published procedures [31,32]. In brief, serum sample $(200 \mu \mathrm{l})$ was aliquoted in to teflon tube and covered with teflon ball. After adding $1 \mathrm{ml}$ of concentrated $\mathrm{HNO}_{3}$ (Wako Pure Chemicals, Japan), the tube was heated on an aluminium heating block (IWAKI, Asahi Techno Glass, Japan) at $120^{\circ} \mathrm{C}$ for 5 hours. The sample was further heated almost to dryness at $200^{\circ} \mathrm{C}$ after removing the teflon ball. Finally, the 
residue was dissolved with $2 \mathrm{ml}$ of $0.1 \mathrm{M} \mathrm{HNO}_{3}$ which contained $10 \mathrm{ng} / \mathrm{ml}$ internal standard elements (In, Re, and $\mathrm{Tl}$ ). The diluted serum solution was used for analysis of the elements in ICP-MS. Commercially available single element standard solutions $(1000 \mu \mathrm{g} / \mathrm{ml})$ were purchased from Wako Pure Chemicals (Osaka, Japan) and used for standardization of calibration curves. The result was expressed in $\mathrm{mg} / \mathrm{dl}$ for calcium and magnesium, and in $\mu \mathrm{g} / \mathrm{dl}$ for copper, iron, zinc, selenium and molybdenum.

\section{Statistical analysis}

Data were analyzed using SPSS version 13 statistical package (SPSS, Inc., Chicago, IL, USA). A one-sample Kolmogorov-Smirnov test was used to assess whether the data were normally distributed. All micronutrients values in serum were normally distributed and hence no transformation was done. Comparisons of serum values of the trace elements among students were made using one-way-ANOVA. Post hoc Tukey test was used to determine which pairs of means differ significantly. Cut off value for magnesium, calcium, iron, copper, zinc, selenium and molybdenum was defined at their serum levels of $1.8 \mathrm{mg} / \mathrm{dl}, 8.4 \mathrm{mg} / \mathrm{dl}, 60 \mu \mathrm{g} / \mathrm{dl}, 75 \mu \mathrm{g} / \mathrm{dl}, 75 \mu \mathrm{g} /$ $\mathrm{dl}, 7 \mu \mathrm{g} / \mathrm{dl}$ and $0.02 \mu \mathrm{g} / \mathrm{dl}$, respectively [33]. Pearson's test was used to assess the correlation between two continuous variables. Statistical significance was assigned for $p$ values less than 0.05 . The $\mathrm{z}$ score values for height-, weight- and BMI-for-age relative to the WHO 2007 reference were calculated using Epi Info and WHO Anthro Plus softwares [34]. The z score values relative to the USCDC 2000 reference were calculated by the SPSS files provided by the USCDC [35].

\section{Results}

The study sample consisted of 100 elementary school children between 10 to 14 years of age (mean age 12.1 \pm 2.4 ). Majority of the school children were males (52\%). Intestinal helminthic parasites were detected in $18 \%$ of the school children (Table 1). Ascaris lumbricoides (10,55.6\%) was the predominant parasite identified followed by hookworm (6, 33.3\%) and Trichuris trichuria (2, 11.1\%).

The means z-scores of HAZ, WAZ and BMI-for-age of the study participants were $-1.15 \pm 1.21,-1.15 \pm 1.00$ and $-0.72 \pm 1.39$, respectively (Table 2 ). The means were not significantly different between females and males in all anthropometric measures used to evaluate their nutritional status. The prevalence for the respective anthropometric measures indicated that $23 \%, 21 \%$ and $11 \%$ of the school children respectively were stunted, underweight and wasted (Table 2). Although not statistically significant, the prevalence rates for stunting and underweight were relatively higher among females.

Table 3 shows the concentrations of serum magnesium, calcium, iron, copper, zinc, selenium and molybdenum in
Table 1 Demographic data of school children at Meseret Elementary School, Gondar, Ethiopia

\begin{tabular}{lll}
\hline Features & & Number (\%) \\
\hline Age & $5-9$ & $11(11)$ \\
& $10-14$ & $79(79)$ \\
& $>15$ & $7(10)$ \\
\hline Gender & Male & $52(52)$ \\
& Female & $48(48)$ \\
\hline Helminths infection & Yes & $18(18)$ \\
\hline Mother education & No & $82(82)$ \\
& Educated & $47(47)$ \\
& Not educated & $53(53)$ \\
\hline
\end{tabular}

school children in relation to nutritional status. The mean serum level of iron was significantly lower in severely stunted compared to moderately stunted school children $(P<0.05)$. There was only a significant difference among different classification of height-for age concerning the copper-to-zinc ratio $(P<0.05)$. Serum concentration of calcium was significantly higher in moderately thin (wasted) school children $(P<0.05)$ compared to normal. However, serum concentration of zinc was significantly lower in mildly wasted school children $(P<0.05)$ compared to normal. On the contrary, severely wasted school children had significantly higher concentration of copper, although not statistically significant. As a result, the copper-to-zinc ratio was significantly higher in mildly wasted school children $(P<0.05)$ compared to normal children.

Table 4 shows the prevalence of multiple micronutrient deficiencies. In this study, $80 \%$ of the school children had two or more coexisting micronutrient deficiencies. Ten percents of these children had three coexisting micronutrient deficiencies. Zinc deficiency occurred in $47 \%$ of the school children, $62 \%$ had selenium deficiency and $2 \%$ had magnesium deficiency. Deficiency for both selenium and zinc was observed in $34 \%$ of the school children (data not shown).

Bivariate correlation analysis showed a significant correlation between $\mathrm{z}$-scores of height-for-age and the levels of magnesium $(\mathrm{r}=0.212, p<0.05)$, copper $(\mathrm{r}=0.275, p<0.01)$ and molybdenum $(\mathrm{r}=0.275, p<0.01)$. No significant correlation was found between the levels of micronutrients and the other anthropometric variables (Table 5).

\section{Discussion}

Malnutrition, protein-energy malnutrition and micronutrient deficiencies continue to be major health burdens in developing countries, particularly in sub-Saharan Africa. It is globally one of the most common risk factor for illness and death, with hundreds of millions of pregnant women and young children particularly affected [36]. For children in developing countries, malnutrition is a considerable health problem with prevalence rates estimated to range 
Table 2 Nutritional status of school children at Meseret Elementary School, Gondar, Ethiopia

\begin{tabular}{|c|c|c|c|c|c|}
\hline Anthropometric index & Boys $(n=52)$ & Girls $(n=48)$ & Total $(n=100)$ & $\begin{array}{l}\text { Mean difference between sexes } \\
(95 \% \mathrm{Cl})\end{array}$ & $\begin{array}{l}\text { P value for difference } \\
\text { (2-tailed) }\end{array}$ \\
\hline Height-for-age & $-1.13 \pm 1.11$ & $-1.18 \pm 1.33$ & $-1.15 \pm 1.21$ & $0.05(-0.43-0.54)$ & 0.8 \\
\hline Z score<-2SD (stunting) & $10(19.2 \%)^{*}$ & $13(27.1 \%)$ & $23(23 \%)$ & & \\
\hline Weight-for-age & $-1.143 \pm 0.99$ & $-1.15 \pm 1.03$ & $-1.15 \pm 1.00$ & $0.003(-0.39-0.40)$ & 0.9 \\
\hline Z score $<-2$ SD (underweight) & $8(15.4)$ & $13(27.1 \%)$ & $21(21 \%)$ & & \\
\hline BMl-for -age & $-0.69 \pm 1.08$ & $-0.76 \pm 1.68$ & $-0.72 \pm 1.39$ & $0.06(-0.49-0.61)$ & 0.8 \\
\hline Z score<-2SD (thinness) & $6(11.5)$ & $5(10.4 \%)$ & $11(11 \%)$ & & \\
\hline
\end{tabular}

${ }^{*} \mathrm{~N}(\%)$.

from $4 \%$ to $46 \%$ with $1 \%$ to $10 \%$ severely malnourished [37]. The results of this study show that the prevalence of stunting observed among school children was $23 \%$, which was in agreement with a finding from the study conducted among preschool children (24\%) in northwest Ethiopia [38]. However, it was much lower compared to previous findings in Gumbrit (50\%) in Ethiopia [39]. Higher prevalence of stunting were observed among school children in Tanzania (42.5\%) [40], and in Malaysia (40.2\%) [41].

The prevalence of stunting remains high in the area and the fact that the prevalence of stunting is much higher than that of underweight and wasting confirms that the major problem is chronic malnutrition. Since, stunting is a type of chronic malnutrition which begins in childhood, supplementing the infants and children with quality complementary food after 6 months of age and at least until age 36 months is required so as to minimize the long-term negative consequences of chronic undernutrition. In addition, investment in sustainable food-based strategies is urgently needed to combat hunger and micronutrient deficiencies [42].

In this study, the prevalence of underweight (21\%) was lower than previous reports from north-western Ethiopia $[38,39]$. Both stunting and underweight were worsened as the study population got older, particularly for boys. This may lead to delayed onset of puberty in the boys. In addition, wasting which is usually caused by a relatively recent illness or food shortage was lower than stunting or underweight indicating that chronic malnutrition is more prevalent in Ethiopia than acute malnutrition.

In the present study, although not statistically significant, a positive correlation was observed between heightfor-age $\mathrm{z}$-score and serum iron levels $(\mathrm{r}=0.139, p>0.05)$. It was also demonstrated that severely stunted school children

Table 3 Levels of serum micronutrients (Mean \pm SD) in relation to children's nutritional status of school children, Meseret school, Gondar, Ethiopia

\begin{tabular}{|c|c|c|c|c|c|c|c|c|c|c|}
\hline & & $\mathrm{N}$ & Magnesium & Calcium & Iron & Copper & Zinc & $\mathrm{Cu} / \mathrm{Zn}$ & Selenium & Molybdenum \\
\hline \multirow[t]{4}{*}{ Height-for-age } & Sever & 7 & $2.17 \pm 0.23$ & $14.12 \pm 2.13$ & $223.02 \pm 18.45^{*}$ & $152.55 \pm 32.01$ & $84.89 \pm 29.31$ & $1.95 \pm 0.64$ & $8.20 \pm 1.54$ & $0.13 \pm 0.10$ \\
\hline & Moderate & 15 & $2.47 \pm 0.28$ & $15.32 \pm 2.00$ & $399.05 \pm 161.45$ & $189.14 \pm 50.50$ & $86.05 \pm 56.29$ & $3.10 \pm 1.91$ & $6.58 \pm 2.45$ & $0.21 \pm 0.12$ \\
\hline & Mild & 32 & $2.39 \pm 0.27$ & $15.16 \pm 1.87$ & $297.80 \pm 132.46$ & $186.89 \pm 47.88$ & $95.10 \pm 39.92$ & $2.23 \pm 0.95$ & $6.23 \pm 2.64$ & $0.21 \pm 0.13$ \\
\hline & Normal & 46 & $2.47 \pm 0.38$ & $15.59 \pm 2.34$ & $342.22 \pm 155.85$ & $200.97 \pm 51.80$ & $80.71 \pm 40.86$ & $2.99 \pm 1.40$ & $6.02 \pm 2.68$ & $0.26 \pm 0.16$ \\
\hline Total & & 100 & $2.42 \pm 0.32$ & $15.31 \pm 2.14$ & $328.19 \pm 148.91 a$ & $191.30 \pm 50.17$ & $86.40 \pm 42.40$ & $2.69 \pm 1.37 a$ & $6.32 \pm 2.60$ & $0.22 \pm 0.15$ \\
\hline \multirow[t]{4}{*}{ Weight-for-age } & Sever & 4 & $2.32 \pm 0.49$ & $14.46 \pm 2.23$ & $215.97 \pm 36.75$ & $172.31 \pm 36.17$ & $73.86 \pm 29.76$ & $2.70 \pm 1.43$ & $7.56 \pm 2.41$ & $0.14 \pm 0.10$ \\
\hline & Moderate & 17 & $2.46 \pm 0.25$ & $15.70 \pm 2.033$ & $375.58 \pm 174.65$ & $195.40 \pm 60.79$ & $78.106 \pm 44.49$ & $3.24 \pm 1.90$ & $5.29 \pm 1.95$ & $0.267 \pm 0.15$ \\
\hline & Mild & 27 & $2.48 \pm 0.29$ & $15.50 \pm 1.95$ & $339.80 \pm 130.17$ & $193.27 \pm 51.19$ & $86.326 \pm 50.97$ & $2.92 \pm 1.63$ & $6.51 \pm 2.51$ & $0.22 \pm 0.14$ \\
\hline & Normal & 52 & $2.39 \pm 0.35$ & $15.15 \pm 2.28$ & $315.30 \pm 150.93$ & $190.40 \pm 47.72$ & $90.13 \pm 37.99$ & $2.39 \pm 0.90$ & $6.47 \pm 2.79$ & $0.23 \pm 0.15$ \\
\hline Total & & 100 & $2.42 \pm 0.32$ & $15.31 \pm 2.14$ & $328.19 \pm 148.91$ & $191.30 \pm 50.17$ & $86.40 \pm 42.40$ & $2.69 \pm 1.37$ & $6.32 \pm 2.60$ & $0.23 \pm 0.15$ \\
\hline \multirow[t]{4}{*}{ BMI-for-age } & Sever & 7 & $2.47 \pm 0.42$ & $15.36 \pm 1.61$ & $333.334 \pm 166.37$ & $214.97 \pm 69.68$ & $86.96 \pm 57.37$ & $3.31 \pm 1.81$ & $6.06 \pm 2.66$ & $0.26 \pm 0.19$ \\
\hline & Moderate & 4 & $2.80 \pm 0.12$ & $18.31 \pm 0.87^{* *}$ & $443.30 \pm 84.87$ & $222.73 \pm 47.02$ & $77.61 \pm 35.79$ & $3.27 \pm 1.37$ & $5.57 \pm 1.08$ & $0.29 \pm 0.05$ \\
\hline & Mild & 23 & $2.44 \pm 0.37$ & $15.40 \pm 2.07$ & $324.75 \pm 153.87$ & $187.91 \pm 45.81$ & $63.74 \pm 32.48+$ & $3.53 \pm 1.75 \neq$ & $5.21 \pm 2.54$ & $0.23 \pm 0.14$ \\
\hline & Normal & 66 & $2.39 \pm 0.29$ & $15.09 \pm 2.16$ & $321.86 \pm 148.36$ & $188.07 \pm 49.36$ & $94.78 \pm 41.96$ & $2.30 \pm 0.99$ & $6.78 \pm 2.58$ & $0.22 \pm 0.15$ \\
\hline Total & & 100 & $2.42 \pm 0.32$ & $15.31 \pm 2.14 a$ & $328.19 \pm 148.91$ & $191.31 \pm 50.17$ & $86.40 \pm 42.40 a$ & $2.69 \pm 1.37 a$ & $6.32 \pm 2.60$ & $0.23 \pm 0.15$ \\
\hline
\end{tabular}

${ }^{\mathrm{a}} P$ value (one-way ANOVA) for the comparison between nutritional status.

${ }^{*} P<0.05$ versus moderate $\mathrm{HAZ}$.

${ }^{*} P<0.05$ versus normal BMIZ.

$+P<0.05$ versus normal $B M I Z$.

$\ddagger P<0.05$ versus normal BMIZ. 
Table 4 Levels of serum Micronutrients (Mean \pm SD) and proportions deficient children (\%) in relation to children's sex, Meseret school, Gondar, Ethiopia

\begin{tabular}{|c|c|c|c|c|c|}
\hline \multirow[t]{2}{*}{ Analytes } & \multicolumn{2}{|l|}{ Boys $\mathrm{N}=52$} & \multicolumn{2}{|l|}{ Girls $N=48$} & \multirow{2}{*}{$\begin{array}{l}\text { Sexes } \\
\text { combined } \\
\text { Deficiency } \\
\text { (\%) } N=100\end{array}$} \\
\hline & Mean \pm SD (Range) & Deficiency (\%) & Mean \pm SD (Range) & Deficiency (\%) & \\
\hline Magnesium & $2.43 \pm 0.38(1.50-3.68)$ & $2(3.8)$ & $2.42-0.24(1.98-2.91)$ & - & $2(2)$ \\
\hline Calcium & $15.42 \pm 2.28(9.35-20.52)$ & - & $15.19 \pm 1.99(11.77-20.11)$ & - & - \\
\hline Iron & $337.60 \pm 167.15(74.49-845.51)$ & - & $317.99 \pm 127.22(116.34-578.04)$ & - & - \\
\hline Copper & $194.46 \pm 50.35(118.24-313.02)$ & - & $187.88 \pm 50.27(107.94-324.96)$ & - & - \\
\hline Zinc & $84.37 \pm 42.45(30.74-211.64)$ & $27(51.9)$ & $88.61 \pm 42.68(27.75-191.25)$ & $20(41.7)$ & $47(47)$ \\
\hline $\mathrm{Cu} / \mathrm{Zn}$ ratio & $2.78 \pm 1.37(0.90-6.56)$ & - & $2.59 \pm 1.38(0.93-6.86)$ & - & - \\
\hline Selenium & $6.07 \pm 2.47(1.70-12.57)$ & $33(63.5)$ & $6.59 \pm 2.73(1.71-12.89)$ & $29(60.4)$ & $62(62)$ \\
\hline Molybdenum & $0.22 \pm 0.14(0.03-0.59)$ & - & $0.24 \pm 0.16(0.05-0.63)$ & - & - \\
\hline
\end{tabular}

had low serum concentrations of iron when compared to normal children. This observation was also observed by other authors [43]. Less intake, poor absorption and the systemic effect of infection and utilization of iron by microorganisms for its growth and multiplication may be responsible for their lower iron status [44]. We did not observe iron deficiency in school children irrespective of sex and helminths infection. A previous study involving children in Ethiopia included a thorough assessment of dietary intake and showed that dietary iron was adequate [45]. Some crops, notably teff, a staple dish of many people in the study area, are high in iron [46] and fermented enset may increase non-heme iron absorption [47]. Moreover, intake of meat which is a source of heme iron in urban areas of the country is good [48]. Heme iron is not only well absorbed than non-heme from plant source food, but also has an enhancing effect on absorption. because of exposure to high iron intake. Non-nutritional factors may be responsible for the anaemia seen in parts of the country.

Magnesium is important in maintaining several cellular functions as it is a natural activator of most enzymes. Magnesium deficiency frequently develops in a wide variety of clinical conditions such as protein-energy

Table 5 Correlation between micronutrients and nutritional status in the school children, Meseret school, Gondar, Ethiopia

\begin{tabular}{llll}
\hline Trace elements & Height-for-age & Weight-for-age & BMI-for-age \\
\hline Magnesium $(\mathrm{mg} / \mathrm{dl})$ & $0.212^{*}$ & 0.003 & -0.189 \\
Calcium $(\mathrm{mg} / \mathrm{dl})$ & 0.161 & -0.026 & -0.150 \\
Iron $(\mu \mathrm{g} / \mathrm{dl})$ & 0.139 & 0.033 & -0.035 \\
Copper $(\mu \mathrm{g} / \mathrm{dl})$ & $0.275^{* *}$ & 0.033 & -0.224 \\
Zinc $(\mu \mathrm{g} / \mathrm{dl})$ & -0.020 & 0.092 & 0.086 \\
Cu/Zn ratio & 0.126 & -0.145 & -0.244 \\
Selenium $(\mu \mathrm{g} / \mathrm{dl})$ & -0.159 & 0.018 & 0.115 \\
Molybdenum $(\mu \mathrm{g} / \mathrm{dl})$ & $0.275^{* *}$ & 0.083 & -0.130 \\
\hline
\end{tabular}

*Correlation is significant at the 0.05 level (2-tailed).

${ }^{* *}$ Correlation is significant at the 0.01 level (2-tailed). malnutrition malabsorption, hypoalbuminaemia, sepsis, hypothermia, etc., conditions that are commonly seen in children in developing countries [17]. In the current study, deficiency in magnesium was observed in the school children of the present study, as $2 \%$ of them had its serum levels $<1.80 \mathrm{mg} / \mathrm{dl}$, particularly in boys. However, this prevalence is much lower than the 20.7\% [19] and 51.9\% [49] deficiency reported in Mexican and Vietnamese children. In addition, consistent with previous study in India [50], serum magnesium levels had significant positive correlations with height-for-age. Lower serum magnesium levels in malnourished children may be due to inadequate intake, malabsorption, diarrhoea, and infection.

The present study demonstrated that normal and high calcium levels were common in school children, deficiency occurred in none of study subjects. This is not in agreement with reports from India and Nigeria [13,14]. A possible explanation for the high serum calcium in our study area may be due to high calcium intake and sun exposure. The staple dish of many people in the study area and its environs is a pancake named enjera made from a cereal called Teff (Eragrostisteff) which has higher calcium than those of wheat, barley, or sorghum [51]. On the other hand, Ethiopia is located in the tropics in the horn of Africa between $3^{\circ}$ and $15^{\circ} \mathrm{N}, 33^{\circ}$ and $48^{\circ} \mathrm{E}$ where there is a large amount of sun exposure. When sunlight is plentiful, relatively high serum 25hydroxyvitaminD3 may give rise to higher serum calcium levels [52]. Ultraviolet light is essential in this reaction. It is worth mentioning that, during infection, macrophages and other immune cells can express $1 \alpha-$ hydoxylase, the enzyme that converts circulating $25(\mathrm{OH})$ D3 into $1,25(\mathrm{OH}) \mathrm{D} 3$, the active form of vitamin $\mathrm{D}$ [53] and increased 1, 25(OH) D3 synthesis may further contribute to increased serum calcium level.

The high prevalence of zinc deficiency among the children has a far-reaching implication, as zinc is an important element performing a range of functions in the body. Zinc is a co-factor for the synthesis of a number of 
enzymes, DNA, and RNA [12]. Zinc deficiency has been associated with poor growth in childhood, reduced immuno-competence, and increased infectious disease related morbidity $[52,54]$. The findings of this study were in agreement with previous studies which have demonstrated the existence of zinc deficiencies among children of school age and early adolescence [55-57]. Several studies globally have documented the relationships between lowered zinc concentrations during childhood and morbidity from infectious diseases and the effect on cognitive development [58].

According to WHO, when the prevalence of zinc deficiency is greater than $20 \%$, intervention to improve zinc status is recommended [59]. As a result, the study recommends planning of sustainable community-based intervention strategies to improve the zinc status of school children through zinc supplementation and fortification of staple foods with zinc are recommended. These interventions are imperative in view of the wellknown adverse consequences of zinc deficiency to the health and quality of life of school-aged children, particularly in terms of academic performance.

The mean level of copper in children of this study higher than those reported for children residing in Khartoum, Sudan [23], for 10-12 years girls of urban Yemeni [60], and for healthy Japanese children [24]. The increased copper levels in serum may be due to a non specific increase in serum concentration of cooper binding protein, ceruloplasmin during acute-phase response against a variety of infections and inflammatory conditions [23].

It is interesting to note that the determination of the copper/zinc ratio has been considered helpful in reflecting the nutritional status of zinc in the human body, better than its content in serum [61]. It was also suggested that the copper/zinc ratio have diagnostic and prognostic values; if the ratio of copper/zinc exceeds 2 (Tables $2 \& 3$ ), it would indicate severity of the infection [61]. In the present study, the ratio of copper/zinc was higher in serum of school children with severe nutritional status.

Like zinc and magnesium, a significantly low level of serum selenium was observed in school children compared to the study in Iran [26]. We observed selenium deficiency in a large number of school children (62\%) and A negative correlation was found between serum selenium levels and height-for-age $(r=-0.159)$. In fact, selenium deficiency has been reported as one of the major health problems in Gondar, Ethiopia [31,32], as in Asia and Africa $[62,63]$. Deficiencies of selenium contribute to the prevalence and severity of iodine deficiency disorders which are the most important and well-known global nutritional problems, primarily in developing countries [18]. Selenium is an integral part of the enzyme glutathione peroxidase, which forms a major cellular defense system against oxidative injury $[13,18]$. Selenium deficiency has been incriminated in the causation of several diseases including malignancies [13]. The diversity of nourishment sources, regional variation and different ethnic diets makes it difficult to extend these results to the whole population; however, it appears that more work is required to define acceptable requirements for selenium and zinc intakes, the prevalence of their deficiencies, and their public health significance.

Serum molybdenum level in this study was higher among school children and its level was positively correlated to height-for-age $(\mathrm{r}=0.275, p<0.01)$. However, mean serum molybdenum concentrations did not differ significantly between different nutritional statuses. In human and animal tissues, the enzymes xanthine dehydrogenase (XD)/oxidase (XO), aldehyde oxidase (AO) and sulfite oxidase (SO) require molybdopterin as cofactor and part of the enzyme molecule $[64,65]$. This is the first study to demonstrate the serum concentration of molybdenum among school children in Ethiopia. More research is required. Without it, the public health significance of serum molybdenum concentration in Ethiopia children and adults will remain uncertain.

It is well known that the relationship between malnutrition and infection is an intimate one, and it is often understood that this is because of impaired immune function. In the present study, we did a stool examinations and the overall prevalence of intestinal parasitic infections amongst the school children was $18 \%$, which is low compared to different studies conducted in different parts of Ethiopia (35.5\% and 83.8\%) [66,67]; the difference may be due to the fact that infection rates

Table 6 Comparison of the mean serum levels of micronutrients in children from different countries

\begin{tabular}{|c|c|c|c|c|}
\hline Micronutrients & $\begin{array}{l}\text { Present work } \\
\text { Average } \\
\text { value }(n)\end{array}$ & $\begin{array}{l}\text { Reported } \\
\text { range of sera } \\
\text { level }(n)\end{array}$ & Country & Reference \\
\hline $\begin{array}{l}\text { Magnesium } \\
(\mathrm{mg} / \mathrm{dl})\end{array}$ & $\begin{array}{l}2.42 \pm 0.32 \\
\mathrm{a}(1.50-3.68)\end{array}$ & $\begin{array}{l}2.2 \pm 0.4(488) \\
1.8 \pm 0.17(243)\end{array}$ & $\begin{array}{l}\text { Mexico } \\
\text { Vietnam }\end{array}$ & $\begin{array}{l}{[19]} \\
{[49]}\end{array}$ \\
\hline Calcium (mg/dl) & $\begin{array}{l}15.31 \pm 2.14 \\
(9.35-20.52)\end{array}$ & $\begin{array}{l}9.4 \pm 0.97(5137) \\
8.96 \pm 0.48(39)\end{array}$ & $\begin{array}{l}\text { India } \\
\text { Nigeria }\end{array}$ & $\begin{array}{l}{[20]} \\
{[21]}\end{array}$ \\
\hline Iron $(\mu \mathrm{g} / \mathrm{dl})$ & $\begin{array}{l}328.19 \pm 148.91 \\
(74.49-845.51)\end{array}$ & $60.9 \pm 30.2(281)$ & Malaysia & {$[22]$} \\
\hline Copper $(\mu \mathrm{g} / \mathrm{dl})$ & $\begin{array}{l}191.30 \pm 50.17 \\
(107.94-324.96)\end{array}$ & $\begin{array}{l}119.5 \pm 34.8(28) \\
111.27 \pm 21.17 \\
(114) \\
109 \pm 17(156)\end{array}$ & $\begin{array}{l}\text { Sudan } \\
\text { Yemen } \\
\text { Japan }\end{array}$ & $\begin{array}{l}{[23]} \\
{[60]} \\
{[24]}\end{array}$ \\
\hline $\operatorname{Zinc}(\mu g / d l)$ & $\begin{array}{l}86.40 \pm 42.40 \\
(27.75-211.64)\end{array}$ & $\begin{array}{l}65.4 \pm 18.9(247) \\
66.4 \pm 21.5(149) \\
122.3 \pm 55(902) \\
92 \pm 13(156)\end{array}$ & $\begin{array}{l}\text { Uganda } \\
\text { South } \\
\text { Africa } \\
\text { Iran } \\
\text { Japan }\end{array}$ & $\begin{array}{l}{[25]} \\
{[55]} \\
{[56]} \\
{[24]}\end{array}$ \\
\hline Selenium ( $\mu g / d l)$ & $\begin{array}{l}6.32 \pm 2.59 \\
(1.70-12.89)\end{array}$ & $7.21 \pm 1.68(216)$ & Iran & {$[26]$} \\
\hline $\begin{array}{l}\text { Molybdenum } \\
(\mu \mathrm{g} / \mathrm{dl})\end{array}$ & $\begin{array}{l}0.23 \pm 0.15 \\
(0.03-0.63)\end{array}$ & $1.75 \pm 0.8$ & USA & {$[65]$} \\
\hline
\end{tabular}

a -range. 
depend on factors such as local personal hygienic and sanitary conditions, ecology and geography, among other factors. This decline can also be attributed to the conduct of mass deworming programmes targeting under five children in many parts of Ethiopia as a component of the Enhanced Outreach Strategy (EOS) started in 2004 [68]. It is therefore suggested that intervention measures have to be strengthened to further reduce intestinal helminthic infection among children and the community. This may include: improving sanitation and personal hygiene through continuous health education, multi-micronutrient supplementation, mass deworming and periodic treatment of the children.

Finally, as summarized in Table 6, results of serum levels of magnesium, calcium, iron, copper, zinc, selenium and molybdenum among children in this study and those reported from different countries has been presented. The levels of serum magnesium, calcium, iron, copper and zinc were higher in this report than reports from other countries $[19-26,55,56,60]$. The average selenium level in the current study participants $(6.32 \pm 2.59 \mu \mathrm{g} / \mathrm{dl})$ is lower to their Iranian counterparts (7.21 \pm 1.68$)$ [26].

A limitation of the present study is lack of detailed information on socioeconomic status, and non-availability of data on dietary intake. Such data may provide useful information to explain the situation of micronutrient status and deficiency in the population studied.

In summary, this study shows that the serum concentration of micronutrients in school children with different nutritional status was altered. The findings of the present study also reveal a high prevalence of zinc and selenium deficiencies, individually as well as concomitantly, among the school children in Gondar. Although prevalence of malnutrition was decreasing in the area $[38,39]$, the prevalence of both malnutrition and intestinal parasitism was not negligible in this population. These calls for the need to undertake multicentre studies in various parts of the country to substantiate the data obtained in the present study so that appropriate and beneficial strategies for micronutrient supplementation can be planned.

\section{Abbreviations \\ ELISA: Enzyme linked immunosorbent assay; WHO: World Health Organization; BMI: Body mass index; SPSS: Statistical Package for Social Science; SD: Standard deviation; IQR: Inter quartile range; HAZ: Height-for- age; WAZ: Weight-for-age.}

\section{Competing interests}

The authors declare that they have no competing interests.

\section{Authors' contributions}

Conceived and designed the study: AK, BA, BF, KT, DW, GY, BM, TA, TY, AM, FO. Performed the laboratory analysis: AK, TY, FO. Analyzed data: AK, BA, BF, $K T, D W, G Y, B M, T A, T Y, A M, F O$. Contributed reagents/materials/analysis tools: AK, BA, BF, KT, DW, GY, BM, TA, TY, AM, FO. Wrote the paper: BA, AK, $B M$. All authors have read and approved of the final version of the manuscript.

\section{Acknowledgements}

The study was financially supported by grants from the University of Gondar, Ethiopia, and Sasakawa Scientific Research from the Japan Science Society (no. 17-241). We are profoundly grateful to the school children and their families who participated in the study and the many people that assisted with this project. The headmasters and teachers are thankfully acknowledged for their assistance and support during data collection.

\section{Author details}

'Department of Medical Biochemistry, University of Gondar, College of Medicine and Health Sciences, Gondar, Ethiopia. ${ }^{2}$ Department of Microbiology, Immunology and Parasitology, University of Gondar, College of Medicine and Health Sciences, Gondar, Ethiopia. ${ }^{3}$ Department of Pediatrics, Addis Ababa University, Addis Ababa, Ethiopia. ${ }^{4}$ Department of Chemical Engineering, University of Tokushima, Tokushima, Japan. ${ }^{5}$ University of Tokushima, Institute of Health Biosciences, Tokushima, Japan.

Received: 18 September 2012 Accepted: 6 December 2012 Published: 13 December 2012

\section{References}

1. UNICEF: A World Fit to the Children: Millennium development goals, specia session on children documents and the convention on the rights of the children. New York

2. Black RE, Allen LH, Bhutta ZA, Caulfield LE, de Onis M, Ezzati M, Mathers C, Rivera J: Maternal and child undernutrition: global and regional exposures and health consequences. Lancet 2008, 371(9608):243-260.

3. Rosalind SG, Yewelsew A, Hambidge KM, Isabel A, Aklilu T, Barbara JS: Inadequate feeding practices and impaired growth among children from subsistence farming households in Sidama, Southern Ethiopia. Matern Child Nutr 2009, 5:260-275.

4. Rayhan I, Khan SH: Factors causing malnutrition among under five children in Bangladesh, Asian Network for Scientific Information. Pak J Nutr 2006, 5(6):558-562

5. Chandra RK: Nutrition and the immune system: an introduction. Am J Clin Nutr 1997, 66:460S-463S

6. Grimble RF: Malnutrition and the immune response 2. Impact of nutrients on cytokine biology in infection. Trans Royal Soc Trop Med Hyg 1994, 88:615-619.

7. Brussow H, Sidoti J, Dirren H, Freire WB: Effect of malnutrition in Ecuadorian children on titers of serum antibodies to various microbial antigens. Clin Diag Lab Immunol 1995, 2:62-68.

8. Redmond HP, Gallagher HJ, Shou J: Antigen presentation in protein energy malnutrition. Cell Immunol 1995, 163:80-87.

9. Girma W. Genebo T: Determinants of Nutritional Status of Women and Children in Ethiopia. Calverton, Maryland, USA: ORC Macro; 2002:38-143.

10. Bárány $E$, Bergdahl IA, Bratteby LE, Lundh T, Samuelson G, Schütz A, Skerfving S, Oskarsson A: Trace element levels in whole blood and serum from Swedish adolescents. Sci Total Environ 2002, 286:129-141.

11. Failla ML: Trace elements and host defense: recent advances and continuing challenges. J Nutr 2003, 133:1443S-1447S.

12. Nicola ML, William DF, Malcolm JJ: Is there a potential therapeutic value of copper and zinc for osteoporosis? Proc Nutr Soc 2002, 61:181-485

13. McKenzie RC, Rafferty TS, Beckett GJ: Selenium: an essential element for immune function. Immunol Today 1998, 19:342-345

14. Gebre-Medhin M, Birgegård G: Serum ferritin in Ethiopian mothers and their newborn infants. Relation to iron intake and socio-economic conditions. Scand J Haematol 1981, 27:247-252.

15. Gebremedihin M: Rarity of anaemia of pregnancy in Ethiopia. Scand J Haematol 1976, 16:168-175.

16. Moreno T, Artacho R, Navarro M, Perez A, Ruiz-Lopez MD: Serum copper concentration in HIV-infection patients and relationships with other biochemical indices. Sci Total Environ 1998, 217:21-26.

17. Rude RK: Magnesium disorders. In Fluids and Electrolytes. 3rd edition. Edited by Kokko JP, Tannen RL. Philadelphia: WB Saunders; 1996:421-445.

18. Hıncal F: Trace elements in growth: lodine and selenium status of Turkish children. J of Trace Elem in Med and Bio 2007, 21:40-43.

19. Rodríguez-Morán M, Guerrero-Romero F: Serum magnesium and C-reactive protein levels. Arch Dis Child 2008, 93(8):676-680.

20. Raman KM, Nikhil T, Devi HK, Rashmi A, Rajvir S, Ramesh CS, Bobbin S, Ashraf G, Satveer S: Vitamin D and bone mineral density status of healthy school children in northern India. Am J Clin Nutr 2005, 82:477-482. 
21. Ayoola OO, Fawole OI, Omotade OO: Calcium and phosphate levels in Nigerian children with malaria. Ann Trop Paediatr 2005, 25(4):303-306.

22. Nor UA, Hesham MS, Azlin M, Shaik A, Sa'iah A, Fatmah MS, Ismail MG, Ahmad F, Aisah MY, Rozlida AR, Norhayati M: Serum iron status in Orang Asli children living in endemic areas of soil-transmitted helminths. Asia Pac J Clin Nutr 2007, 16(4):724-730.

23. Muataz Elsiddig DA, Elmuataz EA: Serum copper in Khartoum: A comparison of children and elderly subjects with healthy adults. Khartoum Medical Journal 2008, 01(03):107-111.

24. Ohtake M, Tamura T: Serum zinc and copper levels in healthy Japanese children. Tohoku J Exp Med 1976, 120(2):99-103.

25. Grace N, James KT, Bjørn JB, Christopher MN, Thorkild T: Zinc status in HIV infected Ugandan children aged 1-5 years: a cross sectional baseline survey. BMC Pediatr 2010, 10:68-75.

26. Safaralizadeh R, Sirjani M, Pourpak Z, Kardar G, Teimourian S, Shams S, Namdar Z, Kazemnejad A, Moin M: Serum selenium concentration in healthy children living in Tehran. Biofactors 2007, 31(2):127-131.

27. Edelstein M, Pitchforth E, Asres G, Silverman M, Kulkarni N: Awareness of health effects of cooking smoke among women in the Gondar Region of Ethiopia: a pilot survey. BMC International Health and Human Rights 2008, 8:10-16.

28. NCHS, CDC Growth charts. U.S. Department of Health and Human Services, Centers for Disease Control and Prevention, National Center for Health Statistics. http://www.cdc.gov/nchs Accessed May 29, 2012.

29. de Onis M, Onyango AW, Borghi E, Siyam A, Nishida C, Siekmann J: Development of a WHO growth reference for school-aged children and adolescents. Bull World Health Organ 2007, 85:660-667.

30. Chesebrough M: Medical laboratory manual for tropical countries. London: Saunders; 1987.

31. Kassu A, Yabutani T, Mulu A, Tessema B, Ota F: Serum Zn, Cu, Se, Ca, and Mg Levels in Pregnant and Non-Pregnant Women in Gondar, Northwest Ethiopia. Biol Trace Elem Res 2008, 122:97-106.

32. Amare B, Tafess K, Ota F, Moges F, Moges B, Andualem B: Serum Concentration of Selenium in Diarrheic Patients with and without HIV/ AIDS in Gondar, Northwest Ethiopia. J AIDS Clinic Res 2011, 2:128-135.

33. Sauberlich HE: Laboratory tests for the assessment of nutritional status. Boca Raton: CRC press; 1999

34. WHO AnthroPlus for personal computers Manual: Software for assessing growth of the world's children and adolescents. Geneva, Switzerland: WHO; 2009. [http://www.who.int/growthref/tools/en/] webcite.

35. Centers for Disease Control and Prevention: Growth charts. [http://www.cdc. gov/nccdphp/dnpa/growthcharts/resources/] webcite.

36. Food and Agriculture Organization of the United Nations: Undernourishment around the world. In The state of food insecurity in the world 2004. Rome: The Organization; 2004

37. Thomas FW, Remon AE, Stephen JS: The interrelationship of malnutrition and diarrhea in a peri-urban area outside Alexandria, Egypt. J Pedia. Gastroentero. Nutr. 2001, 32:189-196.

38. Worku N, Erko B, Torben W, Belay M, Kasssu A, Fetene T, Huruy K: Malnutrition and intestinal parasitic infections in school children of Gondar, North West Ethiopia. Ethiop Med J 2009, 47(1):9-16.

39. Melkie E: Assessment of nutritional status of preschool children of Gumbrit, North West Ethiopia. Ethiop.J.Health Dev 2007, 21(2):125-129.

40. Lwambo NJS, Broker S, Siza JE, Bundy DAP, Guyatt H: Age patterns in stunting and anemia in African school children (7-18 years): a cross-sectional study in Tanzania. Europ J Clin Nutr. 2000, 54:36-40.

41. Zulkifli A, Anuar AK, Atiya AS, Yano A: The prevalence of malnutrition and geohelminth infections among primary school children in rural Kelantan. Southeast Asian J Trop Med Public Health 2000, 31(2):339-345.

42. Combating Micronutrient Deficiencies: In Food-based Approaches. Edited by Thompson B, Amoroso L, FAO \& CABI; 2011:432. ISBN-13: 9781845937140.

43. Alemnji GA, Thomas KID, Durosinmi MA, Taiwo O, Fakunle JB: Hematogram and serum iron status of malnourished Nigerian children. E Afr Med J 1995, 72:605-608.

44. World Health Organization: Management of severe malnutrition. A manual for physicians and other senior health workers. Geneva; 1999:4

45. Adish AA, Esrey SA, Gyorkos TW, Johns T: Risk factors for iron deficiency anemia in preschool children in northern Ethiopia. Public Health Nutr 1999, 2:243-252

46. Kaluski DN, Ophir E, Amede T: Food security and nutrition - the Ethiopian case for action. Public Health Nutr 2002, 5:373-381.
47. Bering S, Suchdev S, Sjøltov L, Berggren A, Tetens I, Bukhave K: A lactic acid-fermented oat gruel increases non-heme iron absorption from a phytate-rich meal in healthy women of childbearing age. Br J Nutr 2006, 96:80-85.

48. Betru S, Kawashima H: Pattern and determinants of meat consumption in urban and rural Ethiopia. Livestock Research for Rural Development. Volume 21, Article \#143, . Retrieved February 3, 2012, from http://www.lrrd.org/ Irrd21/9/betr21143.htm

49. Nguyen VN, Nguyen CK, Nguyen XN, Phan VH, Le TH, Nguyen TL, Fusao O, Tomoki Y, Vu QH, Junko M, Takeshi N, Yutaka N: Micronutrient deficiencies and anemia among preschool children in rural Vietnam. Asia Pac J Clin Nutr 2008, 17(1):48-55

50. Singla PN, Prakash C, Ashok K, Kachhawaha JS: Serum Magnesium Levels in Protein-energy Malnutrition. J Trop Pediatr 1998, 44(2):117-119.

51. National Academy Press: Lost crops of Africa. Washington DC: National Academy Press, Vol I; 1996:215-236.

52. Liam CK, Lim KH, Srinivas P, Poi PJH: Hypercalcaemia in patients with newly diagnosed tuberculosis in Malaysia. Int J Tuberc Lung Dis 1998, 2(10):818-823.

53. Gioconda GB, Jose' FP, Maria DS, Felix M, Alberto O: Undetectable serum calcidiol: not everything that glitters is gold. Clin Kidney J 2012, 5:37-40.

54. Black RE: Therapeutic and preventive effects of zinc on serious childhood infectious diseases in developing countries. Am J Clin Nutr 1998, 68:476-479.

55. Folake OS, Abdulkadir AE, Wilna HOT, Carin EN, Christine SV: Prevalence of zinc deficiency among primary school children in a poor peri-urban informal settlement in South Africa. Health SA Gesondheid 2010, 15(1):1-6.

56. Dehghani SM, Katibeh P, Haghighat M, Moravej H, Asadi S: Prevalence of Zinc Deficiency in 3-18 Years Old Children in Shiraz-Iran. Iran Red Crescent Med J 2011, 13(1):4-8.

57. Thurlow RA, Winichagoon P, Pongcharoen T, Gowachirapant S, Boonpraderm A, Manger MS, et al: Risk of zinc, iodine and other micronutrient deficiencies among school children in North-East Thailand. Eur J Clin Nutr 2006, 60:623-632.

58. Black MM: Zinc deficiency and child development. Am J Clin Nutr 1998 68:464S-469S

59. Benoist B, Darnton-Hill I, Davidsson L, Fontaine O, Hotz C: Conclusions of the Joint WHO/UNICEF/IAEA/IZiNCG Interagency Meeting on Zinc Status Indicators. Food Nutr Bull 2007, 28:S480-484.

60. Jumaan R'a M: Serum Copper, Zinc and Copper/Zinc Ratio and their Relationship to Age and Growth Status in Yemeni Adolescent Girls. Sultan Qaboos University Medical Journal 2008, 8(3):291-299.

61. Hua-Dong LU, Zhi-Qiang W, Yu-Rong P, Tian-Shu Z, Xi-Zhu X, Tian- Wang K: Comparison of serum $\mathrm{Zn}, \mathrm{Cu}$ and Se contents between healthy people and patients in high, middle and low incidence areas of gastric cancer of Fujian Province. World J Gastroenterol 1999, 5:84-86.

62. Hess SY: The impact of common micronutrient deficiencies on iodine and thyroid metabolism: the evidence from human studies. Best Pract Res Clin Endocrinol Metab 2010, 24:117-132.

63. Thorpe R, Ntambue K, Dumont J, Thilly CH, Diplock AT: lodine and selenium deficiency associated with cretinism in Zaire. Am J Clin Nutr 1990, 52:1087-1093.

64. Gropper SS, Yannicelli S: Plasma molybdenum concentrations in children with and without phenylketonuria. Biol Trace Elem Res 1993, 38(3):227-231.

65. WHO: Trace Elements in Human Nutrition and Health. Geneva: World Health Organization; 1996. Prepared in Collaboration with the FAO of the UN and the IAEA.

66. Reji P, Belay G, Erko B, Legesse M, Belay M: Intestinal parasitic infections and malnutrition amongst first-cycle primary school children in Adama, Ethiopia. Afr J Prm Health Care Fam Med. 2011, 3:1-5.

67. Jemaneh $\mathrm{L}$ : Soil transmitted helminth infections and Schistoma mansoni in school children from Chilga district, Northwest Ethiopia. Ethiopian J of Health Sci. 2001, 11:79-85.

68. Federal Ministry of Health: Guidelines for the Enhanced Outreach Strategy (EOS) for Child Survival Interventions. Addis Ababa, Ethiopia; 2004

\section{doi:10.1186/1475-2891-11-108}

Cite this article as: Amare et al:: Micronutrient levels and nutritional status of school children living in Northwest Ethiopia. Nutrition Journal 2012 11:108 